\title{
BARRIERS TO INNOVATION AND COMPETITIVENESS: A CASE STUDY OF RATTAN CRAFT AND FURNITURE SMES IN ACEH
}

\author{
HAMBATAN INOVASI DAN DAYA SAING: \\ STUDI KASUS UKM KERAJINAN DAN MEBEL ROTAN DI ACEH
}

\author{
Ummi Safrianti, Sukardi, and Taufik Djatna \\ Department of Agroindustrial Technology, Faculty of Agricultural Engineering and Technology, IPB University \\ Bogor, Jawa Barat, Indonesia \\ Email: ummisafrianti@gmail.com
}

Makalah: Diterima 20 Januari 2021; Diperbaiki 26 Mei 2021; Disetujui 20 Jui 2021

\begin{abstract}
ABSTRAK
Aceh perlu meningkatkan pertumbuhan industri untuk mengamankan pertumbuhan ekonomi dengan menghasilkan produk-produk inovatif yang memiliki nilai tambah. Beberapa lembaga sudah berupaya untuk mendorong inovasi dan pengembangan di beberapa UKM, namun tidak menunjukkan kemajuan apa pun. Dengan demikian, tujuan dari penelitian ini adalah untuk mengetahui apa saja yang menjadi penghambat UKM rotan di Aceh untuk berinovasi dan berdaya saing. Penelitian sebelumnya telah melihat hambatan inovasi dari perspektif pemilik UKM, namun mereka tidak menangkap hambatan dari perspektif pemerintah dan universitas. Penelitian studi kasus dilakukan pada UKM yang beroperasi di Wilayah Aceh Besar. Penelitian ini menggunakan studi kualitatif melalui wawancara eksploratif. Pengumpulan data wawancara menggunakan teknik purposive sampling. Hasilnya, ada tiga kendala utama yang dirasakan oleh pemilik UKM yaitu bahan baku, akses keuangan, serta keterampilan manajemen dan pemasaran. Dari proses analisis diperoleh hasil bahwa sebagian besar hambatan yang dirasakan oleh pengusaha yang diwawancarai bersumber dari kurangnya transfer pengetahuan dan informasi antar lembaga triple helix. Namun dari analisis triple helix masalah sebenarnya adalah kurangnya informasi dan budaya yang berbeda antara perguruan tinggi dan UKM. Rekomendasi terbaik yang harus diambil oleh para pemangku kepentingan di industri ini adalah untuk mentransformasi universitas menjadi universitas wirausaha.
\end{abstract}

Kata kunci: daya saing, hambatan inovasi, UKM rotan

\begin{abstract}
Aceh needs to improve industrial growth to secure economic growth by producing innovative products with added value. Some institutions have already put efforts to encourage innovation and development in some SMEs, but they have not showed any progresses. Thus, the aim of this research was to understand what were the barriers that prevent rattan SMEs in Aceh to innovate and become competitive. Previous research looked into barriers to innovation from SMEs owner's perspectives, however they did not capture barriers from government and university perspectives. A case study research was carried out in SMEs, operating in Aceh Besar Region. This research employed a qualitative study through an explorative interview. The interview data collection used a purposive sampling technique. The result showed that there were three major barriers that were perceived by SMEs owners, namely raw material, financial access, and management and marketing skills. From analytical process the result shows that most of barriers perceived by entrepreneurs interviewed rooted from lack of knowledge transfer and information between triple helix institution. However, from the triple helix analysis, the real problem was the lack of information and different cultures between universities and SMEs. The recommendation that should be best taken by stakeholders in the industry was to transform university to become entrepreneurial university.
\end{abstract}

Keywords: barrier to innovation, competitiveness, rattan SMEs

\section{INTRODUCTION}

Since the Indonesian government enforced a ban on exporting raw and semi-finished rattan due to sustainability reasons and shortages of raw rattan to be used by local industries, the demand for finished rattan craft and furniture has risen significantly (Myers, 2015). Due to this reason, business actors in this industry were forced to produce a higher quality final product, especially in rural areas. Hence, the government made a serious effort to develop the industry in the capital province and all the places where the industry and raw material existed. One of the rural areas as the main focus is Aceh.

Aceh is one of the provinces with great potential to produce rattan and has a history of people crafting rattan to sustain their livelihood. According to Kemenperin (2007) data, approximately 50\% of Indonesian rattan comes from Aceh. That made Aceh become one of the biggest rattan producers in 
Indonesia and the center of the upstream industry in the industrial ministry's future plan (Kemenperin, 2017). Since 20,000 hectares of land are now available for harvesting rattan without any commission (Sartori, 2016), about 896 SMEs (Small Medium Enterprises) started producing around 97,000 units of end products yearly (Kemenperin, $2019 b)$. With that production capacity, the SMEs can employ about 1750 crafters. It is shown that Aceh is a good place for developing projects for the rattan industry. However, since $75 \%$ of raw rattan was sent to another province, it was unlikely that Aceh SMEs could get the best potential benefit from rattan. If only $25 \%$ of raw rattan was sent and $75 \%$ rattan would become finished goods, SMEs could be more profitable and developed.

Furthermore, rattan SMEs in Aceh still face many barriers that prevent them from being innovative and competitive. Many rattan SMEs in Aceh still rely on traditional and straightforward processes, such as drying rattan in the sun, which during rain results in product ruined with mold, and consequently decreasing the quality of final goods (Maizullaili, 2016). Another barrier is a limited variety of products offered by producers (Grace, 2012). While basket and bucket cover (or lids) remain the most commonly exported product (Sentia et al., 2016), there is not enough information and feedback to allow vendors to innovate and expand their market. Limited information availability also affects knowledge of the production and preservation of traditional tools (Muzakir, 2019). The overall demand for rattan products decreases, affecting farmers' willingness to collect and plant rattan (Sartori, 2016).

One of the focus points in the research to improve innovation is to address the barrier to innovation. Innovation is a necessity for economic development and competitiveness, so innovation is an essential key factor in the competitiveness of a country and a company (Cabral et al., 2012). Small enterprises that could not use innovation as their basis of business model strategy might not be competitive because of no improvement in products and processes (Galia and Legros, 2004). Hence, to improve competitiveness, we need to strengthen the innovation in SMEs. Moreover, since SMEs have many barriers, the best strategy to address the obstacles that prevent innovation from sustaining. Piatier (1984) emphasized that barriers can be grouped in two ways, namely external to the company and internal factors.

Aceh needs to improve the regional economic growth because it is undoubtedly one of the poorest provinces in Indonesia and the province with the lowest income per capita in Sumatra, the island on which Aceh is (BPS, 2018). Thus, Aceh has to explore every possibility from potential economic sectors, including rattan industries, to strengthen the economy. Also, this projection has the potential to increase the employment opportunity by empowering
SMEs to recruit more human resources into the industry. However, to foresee a positive expected impact, an understanding and effort to eliminate the barriers should be performed. A better understanding of the barriers to innovation regarding SMEs is collected to help to address difficulties and help to improve the economy of the country (Teece, 1996).

Reflecting on these problems, the government has actually implemented some projects working together with a university in Aceh. These projects are meant to improve the rattan industry's innovative environment. For instance, Kemenperin held workshops and an exhibition (Kemenperin, 2019a). Rattan handicrafts workshop was also conducted in Banda Aceh by (Disnaker Banda Aceh, 2019). They also opened a workshop facility as well as an exhibition to develop crafters' capabilities. The aim was to improve their skills for innovative activities for rattan crafts and furniture, especially in improving the design (Disnaker Banda Aceh, 2019). Nevertheless, the workshop and investments that the government gave did not bring progress in rattan SMEs' growth as well as the environment condition.

Looking at the measures created by the government and some institutions, it seems that the stakeholders have done some solutions following recommendations from Irjayanti and Azis (2012) to address barriers that exist in the regional innovation system. Nevertheless, the solution did not compel the environment to improve or change. According to Irjayanti and Azis (2012), The Indonesian government has implemented the Triple-helix approach to look forward to the collaboration between the industry and educational institutions in order to enhance the innovative environment in the National Innovation System. Thus, to look deeper into the barriers in the innovation of the rattan industry in Aceh, the triple helix stakeholder perspective towards barriers is essential to be considered apart from the barriers within the SMEs. This strategy is applied to understand the existing barriers better and determine the possible interpretation of the solution.

As a result, from the problem background, the question for this research is "what are the barriers that prevent rattan SMEs in Aceh to innovate and become competitive following government, industry, and university relationship interaction from triple helix". So, the research aims to look further between the barriers faced by SMEs and barriers in terms of triple helix relation in the rattan industry in Aceh. With these questions in mind, it will be recommended to the government or university program to create an innovative and competitive environment by initiating supportive public policy and project plans.

\section{MATERIAL AND METHODS}

A case study research was carried out in SMEs operating in Aceh Besar Region in Aceh province, 
Indonesia. This location was chosen as the location for the study because it has a more significant potential market than other places and the existence of central for rattan furniture and craft SMEs. Figure 1 is given to better understand the research design in flow chart framework illustration. A case study is suitable for investigating how an individual, group, or program changes over time, perhaps due to certain conditions or interventions. However, its major limitation is that when only a single case is involved, we cannot be sure that the findings are generalizable to other situations. Thus, a case study is chosen because this research aims to identify the problem that relies upon the rattan industry that prevents improvement, competition, and innovative environment after the government intervenes to solve the issues. Thus, this qualitative research serves the purpose of problem identification with a case study methodology.

To answer the research question, the research project was started with secondary data collection from articles related to finding the existing condition in Aceh rattan SMEs and the internal and external barriers in Indonesia and generally in other countries as a comparison to the barriers to be found.

The second research phase will use a qualitative study through observation and an explorative interview, which were individually prepared and guided to avoid missing important responses of each respondent in the rattan industry.
The interview data collection will employ a purposive sampling technique. From (Leedy and Ormrod, 2001), in purposive sampling, people or other units are chosen for a particular purpose that has been decided are a typical type of a group or those who represent diverse perspectives on an issue. Hence, the samplings were some respondents who have been determined based on position, knowledge, and other factors that indicate the competence of respondents to the research topic. The selection of rattan SMEs was chosen based on the size, experience in production, and involvement in triple helix collaboration. There will be selected stakeholders based on expert competence. The stakeholders will be entrepreneurs or SMEs' owners, middlemen or supplier agents, government and university organizations representatives linked to SMEs. The role of respondents and the number of them is given in table 1. They will provide their insights and perceptions, so it was possible to evaluate the data. The observation was held in 2019, and the interview was conducted between April 2020 to October 2020. The interview was done face to face as well as online.

Questions for the interview were varied according to the target participants. They include aspects of the respondents' background information and their relation/influence in barriers within the industry and recommendations for future entrepreneurs in the field.

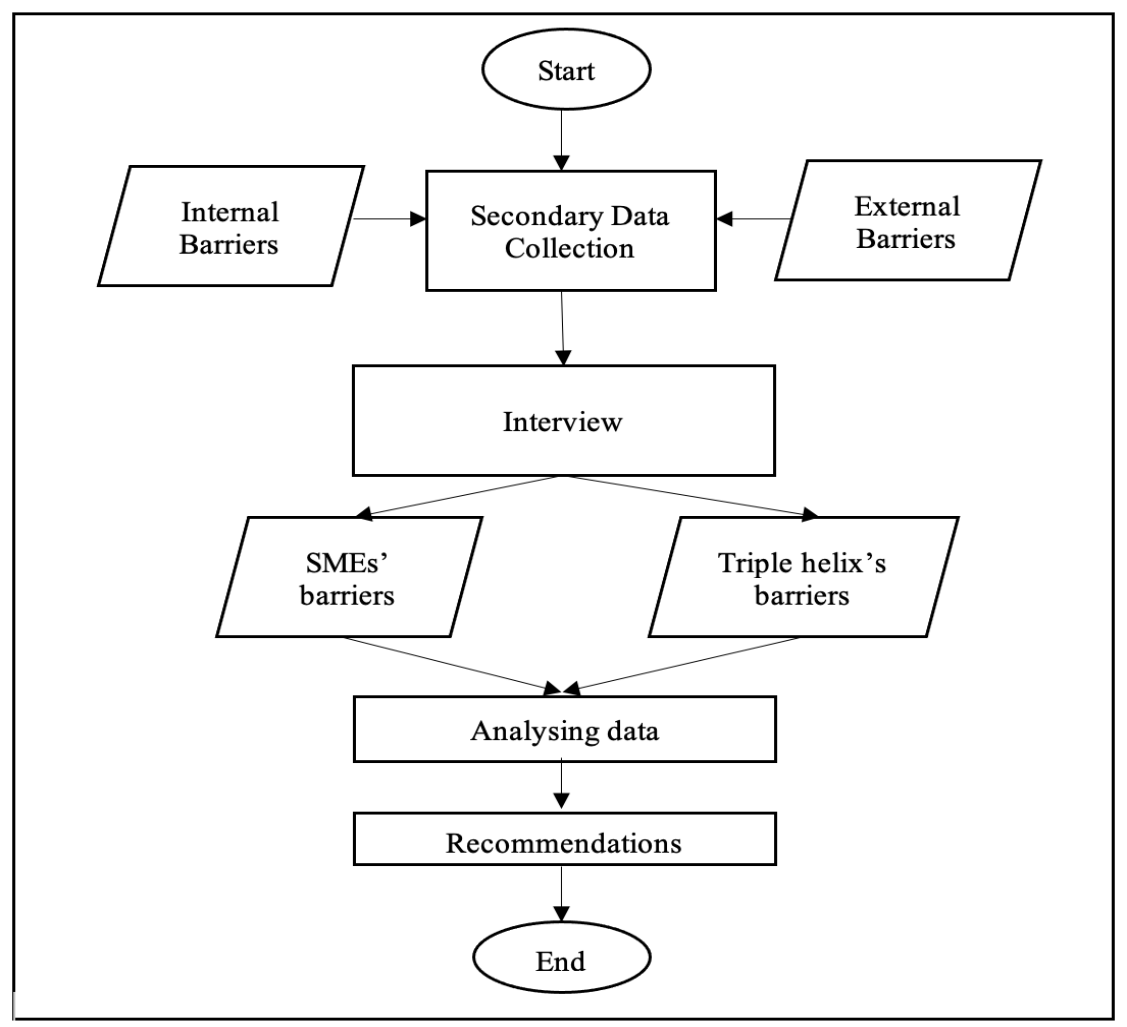

Figure 1. Methodology framework 
They intended to capture the main problems and strategies factors that might affect barriers to innovation and competitiveness proposed in the framework and the coordination between actors in the supply chain and triple helix connection. The obtained results in this first phase will provide a better understanding of the existing barriers. The variables of the research are the barriers that would impact innovation and competitiveness.

Table 1. Role and number of respondents

\begin{tabular}{lc}
\hline \multicolumn{1}{c}{ Stakeholders } & $\begin{array}{c}\text { Number of } \\
\text { respondents }\end{array}$ \\
\hline SMEs owners & 3 \\
Chief of rattan Aceh & 1 \\
organization & \\
Supplier agents & 1 \\
Government and & 1 \\
University mediator & \\
\hline
\end{tabular}

The third phase is synthesizing the qualitative data from interviews that prevent innovation and competitiveness. We identified how barriers related and affected different stakeholders and their implications on the innovation and competition of the industry field. This step is analysed by contrasting and comparing the result from rattan SMEs in Aceh and the findings from another research. Furthermore, analysis is done to identify the root cause in triple helix relation that hamper the improvement in the rattan Aceh SMEs using an Analytical framework. This is done by referring to previous existing articles in Indonesia and international research. The last phase is to generate a recommendation of what action should be taken to overcome the barriers that could become a strategy to be followed by SMEs owner and stakeholders in the rattan industry in Aceh.

The drawback of the study case method used in this research project is the bias that could happen from the project. That researcher could influence the answer of respondents. However, before doing the interview, we have considered this issue and tried to eliminate it by using semi-structured interviews with follow-up questions beforehand and tried not to direct respondents with leading questions. We have also recorded and noted the interview and observations carefully without mixing facts and assumptions for missing essential aspects.

\section{RESULT AND DISCUSSION}

Aceh rattan SMEs center is located in Aceh Besar, particularly in villages called Kueh and Lamgaboh. Middleman is the raw material supplier for SMEs who work directly with rattan collectors and distributors from another area. The middleman has their working plant to polish and cut raw rattan before transporting it to crafters. The middleman has a role in paying farmers to collect the raw rattan to maintain enough stock. A Government-university representative is a researcher and advisor to help support the program held by the government under the educational ministry department. He created a list of funds to give to several SMEs owners and conducted training for rattan SMEs in Aceh.

From the interviews, the rankings of the barriers are based on the frequency of the responses from the interviewee. The percentage of the ranking found from the interview is given in figure 2. The top three barriers focus on (1) Raw material, (2) Financial access, and (3) Managerial capacity. In this research project, it depicts that some SMEs owner shows better awareness than others. Moreover, internal barriers prevent innovation more than external barriers. This statement is consistent with the research from Madrid-Guijarro et al. (2009). The explicit finding from the interview is that most of the barriers perceived by SMEs owner are supported by existed research.

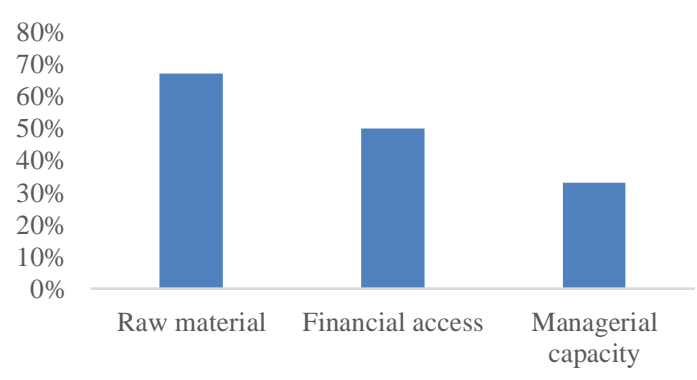

Figure 2. Percentage of barriers rank

\section{Raw Material}

A total of $67 \%$ of interviewee perceived that lack of or high /inconsistence price of raw material that hampers the innovation. This finding is consistent to the research from Tambunan (2009), in which he stated that raw material is the constraint for several countries in Asia namely Indonesia, Laos, Thailand and Malaysia. This also consistent with the result from Irjayanti and Azis (2012) and Sama (2011), that obtaining raw material on time is the barriers to be solved in Indonesia and Tanzania to be able to increase the economic state of SMEs.

From the interview, the inconsistency of prices for purchasing raw material is occurring in rattan industry according to SMEs owners. In the middleman's point of view the constraint from raw material is rooted from the difficulty to order farmers to collect rattan from the woods due to financial issues. The middleman prefers to prioritize the material to buyer from other provinces because bulk and regular buying. However, middleman will have the rattan supply from Medan. This rattan is different from the rattan from Aceh, the material quality is not as good as Aceh rattan and the price is fluctuated due to economic factors such as transportation fee.

This finding shows that there is a necessity of well interaction between suppliers and the SMEs. According to Uyarra et al. (2014) innovation system 
approach emphasize the interactive relationship between procurement actors to produce innovation. This interaction can build trust to reduce costly monitoring and misinformation, as well as knowledge transfer about the industry from the supplier that is not available in the SMEs (Tambunan, 2009). However, this interaction can be hampered by lack of skill and knowledge about procurement procedures. Because of this barrier, the SMEs cannot meet the standard of competing with another province and also another country. The university and government representative stated that most of the SMEs could not fulfill the order capacity. One of the reasons for this issue is the scarcity of the raw material due to fluctuated price.

The interaction between supplier and business owner often hindered by having no appropriate quality of communication (Uyarra and Flanagan, 2010). This communication is needed to gain a settlement of satisfactory stable price where both parties can create a justifiable contract. With this measure the trust between two parties will establish and hence solve the problem of preference to send to another country from middleman. However, to get a well-managed amount of raw material to order the SMEs need to have knowledge on how to do production planning as well as procurement process to avoid miscalculation from ordering to meet the demand. According to Caldwell et al. (2009) the quality of communication is more significant than the number of people involved in the procurement process.

Raw material issue has been a problem in this sector for a while not only in Aceh but also in another part of Indonesia that has rattan production. A way to address this dilemma is by having a better procurement capability applied on the business in which it can create an engagement from supplier, user of the material and the end user of finished product. However, the rattan industry in Aceh still has a traditional concept of relation with purchasing material for production. They still order in time when there is a need to produce in random time. Moreover, the entrepreneurs still need to visit the supplier to choose the material due to lack of trust in the relation. Thus, the entrepreneurs should be enlightened on how to keep a balance between supply and demand and plan it beforehand to secure the dynamic of scarcity of raw material.

\section{Financial Access}

Most of major barriers in different study is associated with financial issues and cost-related constraints. In this case study, this barrier becomes the second barriers $(50 \%)$ because the SMEs owner have got some funds stimulation and knowledge on how to get a loan from bank or another firms. However, Due to the relatively high-risk profile that SMEs possess, commercial banks and investors are reluctant to provide financial support (Tambunan, 2009). This situation became more serious by dynamic environment and miscommunication, lack of loan guarantee and integrated relation, and some vague property rights and creditors' rights in the event of collapsing business. Nevertheless, the funds barriers mostly come from the middleman who is failing to fund the farmers to sustain their life to be able to keep collecting rattan. Hence, they have multiple jobs or prefer another job. The middleman has to invest some amount of money before the farmers giving the rattan they will collect. Tambunan (2009) stated that Those who faced capital constraint were mainly SMEs located in rural or backward areas, and they never received any credit from banks or other financial firms. They mainly rely on their own savings, money from relatives or from informal lenders. In the case study, the entrepreneurs feel reluctant to get a loan because of the risk and complicated administration when returning the money as well as lack of information on the interest have to pay.

This finding is relevant to the study of MadridGuijarro et al. (2009) that the factor which affect innovation the most is cost associated barriers, moreover, the financial barriers is more significant especially in small firms compare to larger business. Olawale and Garwe (2009) and Najda-Janoszka and Kopera (2014) also stated that financial is internal factor which affect the innovation and that the entrepreneurs who perceived innovation as expensive expense will avoid innovation.

A stable financial position contributes to competitive business. However, most of SMEs often lack working capital. According to (Gebrewahid and Wald, 2017; Kasseeah et al., 2013) this will add problem to the business and will exacerbate the condition in the entire working process. A lack of working capital often does not synchronize with the need for the cost of market research, changes of currency, transportation and accommodation bill, insurance and risk of international sales. They mentioned that international market needs a significant focus on market research, visiting the country of buyer, and adapting the environment and strategy of the business which need more capital to be given. Hence this creates financial burden for SMEs in developing countries, especially in rural area.

While the financial burden hampers the competition with another businesses, this issue also preventing the business to do innovation activity. This happened because they still cannot secure the daily needs of a business in achieving the first goal that is gaining adequate profit. Hence, the entrepreneurs have a spreading focus and the priority that likely to be chosen is to maintain the stability of the income.

The strategy to solve this barrier is by finding different source of funding instead of only relying on their own financial and family as well as government 
help. Even though they have received some funds, the observation showed that they are still unable to create different financial management such as accounting instruments, for example cash flows and balance sheets, not to mention income statement to attract investors to invest in the business. Thus, the most reliable suggested strategy is involvement of the government to offer the knowledge on how to do accounting for the business.

\section{Management Skill}

The third biggest barrier that is mentioned by interviewee is management skill with 33 percent of weight. The rattan training advisor stated that most of the entrepreneurs could not manage their schedule in production to fulfill the need of demand. Muzakir (2019) summarized that the management level of most SMEs in Aceh Besar is not maximized yet and inadequate. Furthermore, they fail to commit to satisfy the customer that ask for bigger order which mainly the international customers. Hence, they only sell to local buyer with just a small amount.

This finding is consistent with the study of Madrid-Guijarro et al. (2009) that found human resources have a slight negative impact on innovation. They find that the evidence of lack of management commitment is the prove of what hamper and prevent innovation. This is recognized from resistance to change, some of which results from inadequate training or poor skills, is an important organizational challenge. They pointed out that small business managers often lack the types of education and training that have been linked with a successful innovation strategy.

Marketing knowledge is an essential skill as well as the information of the market to achieve higher return on exporting products. Understanding the market entry, market opportunity and the information about the strategy in the environment can reduce the willingness of a business to try to expand and start to have international market (Gebrewahid and Wald, 2017). But many businesses face the barriers with identifying international market effectively, especially small firms with lack of capital and management skill. These firms mostly face difficulty due to source, quality, and information access (Czinkota and Ronkainen, 2013). These issues later hinder the capability of entrepreneurs to conduct an innovation activity due to lack of marketing skill.

From the interview result, it shows that there were two of SMEs owners show more willingness to gather knowledge by joining workshop and training. However, because the frequency of the training and the workshop is still a few they still cannot a proper application in the real rattan business situation especially considering different situation in the culture and environment. One of them stated that the most of workshop is mainly about crafting design. This shows that the insufficient of knowledge happened from lack of knowledge transfer.
To address this problem immediately, there is a need for entrepreneurs to have a strong will to pursue business knowledge as well as motivation to have a growing business without relying on the existing system. The urgent basic skill set that is significant to gather are accounting, management and marketing skill, production and procurement skill and inventory issues. However, to solve the issues in the environment and the innovation system the policy makers have to manage the relation between actors that works on progressing the business in the area.

\section{Triple Helix perspectives}

The main barriers analysed from interview about barriers to innovation show a strong link to lack of knowledge from SMEs owners. Even though raw material is the barriers perceived by the most respondents, but it can be solved with better management commitment between supplier and entrepreneur. Financial is another big problem, however the fact that government has already did some of the measure to help the issue does not help the situation it can be recognized as the problem in the knowledge to organize the funds. From the interview and observation, we find that there were half of the respondents actively engaging in a closer relation with triple helix institution. This draw a line with a conclusion that they were more willing to change their entrepreneur character and improve their skill set relating to the business development. However, according to them the number of events held by the institution to help SMEs is still not often. Hence, the main problem is the lack of knowledge transfer. However, the SMEs owners could not change themselves without proper boost or strong motivation to change.

According to Razak and White (2015) the barriers within triple helix institution are the inactive relation between institution and vague status of each stakeholders. This is also found from the finding that there was no clear status and role between the government, university and industry which was SMEs. The lack of university-industry collaboration has been mentioned by several researchers, as the consequence of the lack of focus by governments in devising and implementing policies. Ranga and Etzkowitz (2010) have highlighted that the government needs to focus on policies for industrial development and educational resources to transform the universities from being teaching institutions to being more entrepreneurial.

The main barriers of rattan SMEs in Aceh is due to a distant connection between different actors are the lack of information and different culture within university and industries. Moreover, the culture in Indonesia and especially Aceh is still far from adequate innovative and competitive culture. The consisting current relation from the triple helix connection is as shown in figure 3 . The current government and university involvement already 
happened from several organization. These are PLUT (Pusat Payanan Usaha Terpadu) or Center for integrated small business service firm, Kemenperin or ministry of industry, and Kemendikti or ministry of higher education that focus on research and technology.

Razak and White (2015) argue that the reason for the lack of information networking is due to different value or goal from the triple helix institution. University value publication and scientific procedural while industry do not trust university as their solution is less practical. So, their recommendation for this problem is similar to what suggested by Ranga and Etzkowitz (2010) that university should become more entrepreneurial and create a commercial arm such as business incubator and science park. With this approach both will have a same value and university will value the firms who will invest. The initiation of business incubator has already been done but it is still in early development. However, reflecting on the result study from Razak and White (2015), there is a problem of inactive relation and vague and symbolic contribution.

The government role here is by creating the link for the cooperation between SMEs and university by creating specific policies or giving funds to enable SMEs to join incubators program. Irawati (2006) mentioned in her study that Indonesian universities have a principle that universities should serve not only for achieving education but also research and community service or which is called tri dharma. Hence, with this in mind, it is not so difficult but challenging to stir the situation to enable the university to take the role as basis for knowledge transfer. The university in Aceh have been doing regular community service annually for part of student compulsory to graduate. It will be beneficial to encourage the management and marketing skill to SMEs under university and government supervision. Furthermore, following research center that has existed, university in Aceh should steer the direction to Science Park to leverage the economy by transferring knowledge to the local small businesses.

\section{DISCUSSION}

The aim of this paper was to shed a light on the barriers related to innovation and competitiveness from rattan industry in Aceh that prevent them to be competitive from other province and export activities. The purpose of this study is to identify the problem which relies in the case study area. Unlike the assumption that there will be a different finding unique to the case, the research find that the barriers perceived by entrepreneurs are relatively similar and relevant to the previous study. Even though there were differences on what mostly perceived as the first barriers in the global company and entrepreneurs the findings were still showing a similar result. However, even though similar, an enterprise or an industry need to conduct a research on what hamper their business to receive the best benefit of innovation and competition. This statement is supported by the study of Cordeiro and Vieira (2012) in her review about barriers to innovation for international comparison. This is important to be done in order to tailor a suitable strategy for the businesses to get the best potential outcome. Furthermore, the policy maker as well as the actors involved in the industry could acknowledge which measure should be taken first to improve the existing condition.

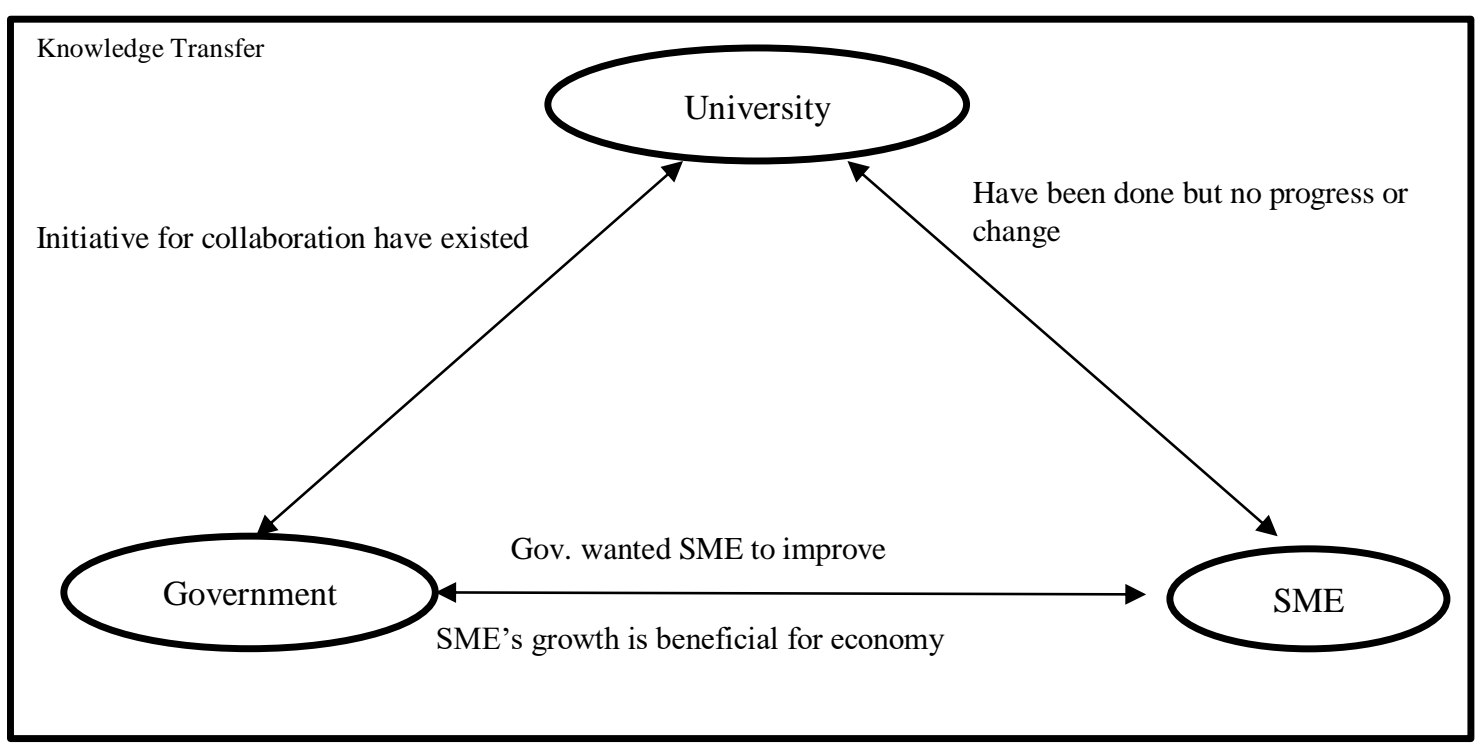

Figure 3. The current relation within triple helix institution 
Similar to barriers perceived by entrepreneur in the field, barriers in the triple helix relation were also supported by research from different researchers. However, the study regarding the existing interaction between triple helix factors unexpectedly finds that SMEs which strongly related and have a good relation to triple helix linkage shows more awareness of barriers, thus they have stronger motivation to change (self-efficacy) as well as to innovate especially in product design and to be more competitive. The active relation is shown by good communication in the networking environment and the willingness to join training and workshops, especially in another provinces. Hence, it makes the entrepreneurs could strive greater than the those who reluctant to participate or just feels forced to participate.

This is supported by finding that stated selfefficacy is weak in stable environment, on the other hand, it is stronger in uncertain environment (Hmieleski and Baron, 2008). According to Johnson and Delmar (2009) in uncertain environment, entrepreneurs feel more motivated to solve problems. The more aware entrepreneurs with the barriers the more they feel the need to normalize the situation by solving the barriers. However, further investigation on the relation suggested could be well researched in the future study that focus on this aspect.

This research result is just a part of primary research that the writer has done. The next part of the research is to create a strategy model based on the findings from barriers within triple helix institutions relation. This study has a limitation by not including the farmers view for further understanding within the case study. The recommendation of future research is to conduct research with broader respondents and using a survey approach.

Moreover, this research is limited by the case study area, where only rattan SMEs in Aceh especially in Aceh Besar are represented. However, there are similarities with other SMEs related to rattan or agricultural industry, especially in neighboring states and countries, which could be also analyzed in future studies.

\section{CONCLUSION AND RECOMMENDATIONS}

The purpose of this research is to identify the main barriers that challenging the improvement of rattan SMEs in Aceh. To get the desired answer, the research applies a case study method which serve problem identification purpose of qualitative research. This method employs an explorative interview with purposive sampling and analytical framework. Therefore, the result from this research was there were three major barriers that were perceived by SMEs owners namely raw material, financial access, and management and marketing skill. From analytical process the result shows that most of barriers perceived by entrepreneurs interviewed rooted from lack of knowledge transfer and information between triple helix institution.

To conclude, the recommendation to address this problem is by advising government to encourage university to become more entrepreneurial by building effective business incubation by creating specific policies or giving funds to enable SMEs to join incubators program. The other alternatives are by giving a management and marketing skill to SMEs in every possible way. Through the help of the training, the entrepreneur could create a contract or agreement to manage the supply problem. Furthermore, recommendation to start building science park that empower SMEs in Aceh.

\section{REFERENCES}

BPS. 2018. Gross domestic products by industrial origin, Indonesian government. Retrieved 3 October $2020 \quad$ from http://www.bps.go.id/eng/pdb.php

Cabral J, Coelho A, Coelho F, Costa M. 2012. Capabilities, innovation and performance in Brazilian export firms.

Caldwell ND, Roehrich JK, and Davies AC. 2009. Procuring complex performance in construction: London Heathrow Terminal 5 and a Private Finance Initiative hospital. Journal Purchasing and Supply Management. $\quad 15(3): \quad$ 178-186. https://doi.org/https://doi.org/10.1016/j.purs up.2009.05.006

Cordeiro A and Vieira FD. 2012. Barriers to innovation in SMEs: An international comparison.

Czinkota MR and Ronkainen IA. 2013. International marketing. Cengage Learning.

Disnaker Banda Aceh. 2019. Pembukaan pelatihan handicraft berbahan rotan di pangoe raya. Retrieved 2 March 2020 from http://disnaker.bandaacehkota.go.id/2019/0 9/18/pembukaan-pelatihan-handicraftberbahan-rotan-di-pangoe-raya/

Galia F and Legros D. 2004. Complementarities between obstacles to innovation: evidence from France. 33(8): 1185-1199. https://doi.org/10.1016/j.respol.2004.06.004

Gebrewahid GG and Wald A. 2017. Export Barriers and Competitiveness of Developing of African Business. 18(4): 396-416. https://doi.org/10.1080/15228916.2017.132 $\underline{9475}$

Grace H. 2012. Perkembangan Material Rotan dan Penggunaan di Dunia Desain Interior. Humaniora Binus. 3(2): 494-503.

Hmieleski KM and Baron RA. 2008. When does entrepreneurial self-efficacy enhance versus reduce firm performance? Strategic Entrepreneurship Journal. 2(1): 57-72. https://doi.org/https://doi.org/10.1002/sej.42 
Irawati D. 2006. Understanding The Triple Helix Model from The Perspective of the Developing Country: A Demand or A Challange for Indonesian Case Study? University Library of Munich, Germany, MPRA Paper.

Irjayanti M and Azis AM. 2012. Barrier Factors and Potential Solutions for Indonesian SMEs. Procedia Economics and Finance. 4: 3-12. https://doi.org/10.1016/s22125671(12)00315-2

Johnson A and Delmar F. 2009. The Psychology of Entrepreneurs: A Self-Regulation Perspective. Historical Foundations Entrepreneurship Research. https://doi.org/10.2139/ssrn.1752103

Kasseeah H, Ancharaz VD, Tandrayen-Ragoobur V. 2013. Access to Financing as a Barrier to Trade: Evidence From Mauritius. Journal African Business. 14(3): 171-185. https://doi.org/10.1080/15228916.2013.844 $\underline{032}$

Kemenperin. 2007, 04 December 2019. Kementerian Perindustrian : Pengembangan industri pengolahan rotan indonesia. Retrieved 04 December 2019 from https://www.kemenperin.go.id/

Kemenperin. 2017. Aceh jadi basis produksi rotan dan pariwisata, Indonesian government. Retrieved 2 March 2020 from https://kemenperin.go.id/artikel/5366/AcehJadi-Basis-Produksi-Rotan-dan-Pariwisata

Kemenperin. 2019a. Aceh genjot rotan olahan. Retrieved 3 March 2020 from https://kemenperin.go.id/artikel/6387/AcehGenjot-Rotan-Olahan

Kemenperin. 2019b. Rotan mutlak diolah. Retrieved 2 March 2020 from https://kemenperin.go.id/artikel/6386/Rotan -Mutlak-Diolah

Leedy PD and Ormrod JE. 2001. Practical research : planning and design. Merrill Prentice Hall.

Madrid-Guijarro A, Garcia D, Van Auken H. 2009. Barriers to Innovation among Spanish Manufacturing SMEs. Journal of Small Business Management. 47(4): 465-488. https://doi.org/10.1111/j.1540627x.2009.00279.x

Maizullaili. 2016. Peran perempuan pengrajin rotan dalam meningkatkan pendapatan keluarga di gampong lamgaboh lhoknga. Universitas Syiah Kuala Journal. 152: 456-475.

Muzakir U. 2019. Science and technology for the export product of small and medium sized Enterprise (UKM) Kotaraja Rattan. Jurnal Ilmiah Peuradeun. 7(3): 551. https://doi.org/10.26811/peuradeun.v7i2.31 $\underline{2}$
Myers R. 2015. What the Indonesian rattan export ban means for domestic and international markets, forests, and the livelihoods of rattan collectors. Forest Policy and Economics. 50, 210-219.

https://doi.org/10.1016/j.forpol.2014.07.009

Najda-Janoszka M and Kopera S. 2014. Exploring Barriers to Innovation in Tourism Industry The Case of Southern Region of Poland. Procedia - Social and Behavioral Sciences. 110:

190-201. https://doi.org/10.1016/j.sbspro.2013.12.86 $\underline{2}$

Olawale F and Garwe D. 2009. Obstacles to the growth of new SMEs in South Africa: A principal component analysis approach. Afr. Journal Business Management. 4.

Piatier A. 1984. Barriers to Innovation. France : Pinter.

https://books.google.com.au/books?id=vgO OAAAAIAAJ

Ranga M, Etzkowitz H. 2010. Ranga, M. and H. Etzkowitz (2010), 'Creative Reconstruction: A Triple Helix-based Innovation Strategy in Central and Eastern Europe Countries', In: M. Saad and G. Zawdie (eds), Theory and Practice of Triple Helix Model in Developing Countries. Issues and Challenges, Routledge. In.

Razak AA and White GRT. 2015. The Triple Helix model for innovation: a holistic exploration of barriers and enablers. International Journal Business Performance and Supply Chain Modelling. 7(3): 278. https://doi.org/10.1504/ijbpscm.2015.07160 0

Sama H. 2011. Challenges and opportunities of Tanzanian SMEs in adapting supply chain management. African Journal Business Management. 5:1266-1276.

Sartori S. 2016. Synergies with government expand impact of sustainable rattan : SWITCH-Asia Project Prospect Indonesia. Retrieved 3 December 2019 from https://www.switchasia.eu/news/synergies-with-governmentexpand-impact-of-sustainable-rattan/

Sentia P, Sastra HY, and Ilyas I. 2016. Peningkatan Nilai Tambah Produk Kerajian Rotan Dengan Penerapan Konsep Eco-Design di Desa Kueh Aceh Besar. TI Unsyiah Journal. 5:

https://doi.org/10.13140/RG.2.2.35589.555 $\underline{29}$

Tambunan T. 2009. SMEs in Asian Developing Countries. London : Palgrave Macmillan. https://doi.org/10.1057/9780230250949

Teece DJ. 1996. Firm organization, industrial structure, and technological innovation. Journal Economic Behavior \& 
Organization. 31(2): 193-224. Uyarra E, Flanagan K. 2010. Understanding the https://doi.org/10.1016/s0167- Innovation Impacts of Public Procurement. 2681(96)00895-5

Uyarra E, Edler J, Garcia-Estevez J, Georghiou L, Yeow J. 2014. Barriers to innovation European Planning Studies. 18(1): 123-143. https://doi.org/10.1080/0965431090334356 through public procurement: A supplier 7 perspective. Technovation. 34(10): 631-645. https://doi.org/https://doi.org/10.1016/j.tech novation.2014.04.003 